Porkoláb Imre ezredes - Hőnich Artúr:

\title{
A NATO ÚTJA A DIANA LÉTREHOZÁSÁIG ÉS FÖBB FÓKUSZTERÜLETEI A VÉDELMI INNOVÁCIÓ KERETÉBEN
}

\section{DOI: $10.35926 /$ HSZ.2021.6.2}

ÖSSZEFOGLALÓ: A NATO 2021. júniusi brüsszeli csúcstalálkozóján minden korábbinál részletesebben foglalkoztak a feltörekvő és felforgató technológiák kérdéskörével, valamint a védelmi innováció terén két új intézmény létrehozásáról is határoztak. Az újonnan létrehozandó intézmények tekintetében a DIANA betüszóval fémjelzett Észak-atlanti Védelmi Innovációs Akcelerátor (Defence Innovation Accelerator for the North Atlantic) és a NATO Innovációs Alap (NATO Innovation Fund) biztosítanak szervezeti támogatást a kettős felhasználású technológiák fejlesztésén dolgozó startupok számára. A tanulmány feldolgozza a NATO útját a védelmi innovációs törekvések területén, és ajánlásokat fogalmaz meg a hazai védelmi ipar, valamint a haderő számára, amelyek segítségével kapcsolódni tud a NATO-kezdeményezésekhez.

KULCSSZAVAK: innováció, modernizáció, Magyar Honvédség, védelmi ipar, NATO, stratégiai elörelátás

\section{BEVEZETÉS}

A NATO 2021. júniusi brüsszeli csúcstalálkozóján a szövetséges állam- és kormányfők minden korábbinál részletesebben foglalkoztak a feltörekvő és a felforgató technológiák ${ }^{1}$ kérdéskörével, valamint a védelmi innováció terén két új intézmény létrehozásáról is határoztak. A zárónyilatkozat érvelése szerint „,[a] technológiai változások sebessége soha nem volt még ilyen gyors, ami új lehetöségeket és kockázatokat teremt a biztonsági környezetben és a NATO müködésében".2

A NATO vezetői által elfogadott Koherens Végrehajtási Stratégia ${ }^{3}$ szintén egyértelművé teszi, hogy a feltörekvő és felforgató technológiák azonosítására, kifejlesztésére és megfelelő sebességgel történő alkalmazására kiemelt figyelmet kell fordítani, az operatív végrehajtás során pedig a felelős felhasználás elveit és a nemzetközi jog normáit kell követni.

1 A „feltörekvő és a felforgató technológiák” kifejezés a NATO által használt Emerging Disruptive Technologies (EDT) magyar megfelelője - a szerzők szerint ez a kifejezés adja át legjobban a NATO által használt terminológia jelentéstartalmát.

2 Brussels Summit Communiqué - Issued by the Heads of State and Government participating in the meeting of the North Atlantic Council in Brussels 14 June 2021. NATO E-Library, 14. 06. 2021., 37. bek. https://www.nato. $\mathrm{int} / \mathrm{cps} / \mathrm{en} /$ natohq/news_185000.htm?selectedLocale=en (Letöltés időpontja: 2021. 08. 04.)

3 NATO: Emerging and disruptive technologies. 2021. június 18. https://www.nato.int/cps/en/natohq/topics_184303. htm (Letöltés időpontja: 2021. 08. 04.) 
Az újonnan létrehozandó intézmények tekintetében a DIANA betüszóval fémjelzett Észak-atlanti Védelmi Innovációs Akcelerátor (Defence Innovation Accelerator for the North Atlantic) és a NATO Innovációs Alap (NATO Innovation Fund) biztosítanak szervezeti támogatást a kettős felhasználású technológiák fejlesztésén dolgozó startupok számára. ${ }^{4}$ A DIANA éppen ezért nem kifejezetten katonai, hanem egy hibrid, polgári-katonai intézményi formában lesz felállítva, hogy fellendítse a kritikus technológiák terén a transzatlanti együttmüködést, előmozdítsa az interoperabilitást és fejlessze az együttmüködést a tudományos világgal, valamint a magánszektorral - köztük a startup vállalkozásokkal. ${ }^{5}$

A tervek szerint a DIANA 2023-ra érné el a kezdeti műveleti képességet, tevékenysége pedig lefedné a NATO által a Koherens Végrehajtási Stratégiában megjelölt hét technológiai prioritás mindegyikét. Az elképzelés szerint a DIANA egy észak-amerikai és egy európai központon túl számos további tagállamban jelen lenne fizikailag is irodák, illetve müszaki vizsgálóállomások és kutatóintézetek létesítésével. ${ }^{6}$ A NATO reményei szerint a DIANA akcelerátori tevékenysége erősítené a tagállamok ipari bázisát, áthidalná az innovációs hiányosságokat, valamint biztosítaná, hogy a Szövetség gyorsabban tudjon alkalmazkodni a jelenlegi biztonságpolitikai kihívásokhoz, képes legyen rendkívül rövid idő alatt átvenni és rendszeresíteni új technológiákat annak érdekében, hogy a technológiák megjelenésével párhuzamos adaptív alkalmazás révén folyamatos stratégiai versenyelőnyt biztosítson a tagállamoknak. ${ }^{7}$

A NATO Innovációs Alap kapcsán a hírek egymilliárd eurós tőkealapról szóltak, ami „,seed”, azaz magvetö szerepü, és amit ,,early stage”, azaz korai szakaszukban lévő startupok támogatására különítenének el. ${ }^{8}$ David van Weel, a Szövetség - új biztonsági kihívásokkal foglalkozó - fötitkárhelyettese azt nyilatkozta, hogy az Innovációs Alap napi szintü müködtetését a kockázatitőke-piacon tapasztalt cégekre bíznák, ugyanakkor a tőkealap pénzügyi keretét a projektekben részt vevő NATO-tagállamok biztosítanák, illetve az Alap müködésének fö irányvonalait is a Szövetség határozná meg. ${ }^{9}$ Mindezek alapján egyértelmü, hogy a NATO védelmi innovációs törekvései új szakaszba értek, és a közeljövő fő kérdése, hogy az egyes tagállamok, köztük Magyarország hogyan képzelik el együttmüködésüket a DIANA-val, illetve miként látják részvételüket az Innovációs Alapban.

Tanulmányunkban bemutatjuk azt a viszonylag hosszú utat, amely elvezetett idáig, fókuszba helyezve azokat a stratégiai dokumentumokat, amelyek keretet adnak a NATO jelenlegi védelmi innovációs törekvéseinek. Írásunk zárásaként ajánlásokat fogalmazunk meg arra vonatkozóan, hogy mindez milyen lehetőségeket biztosíthat hazánk számára, hogyan tud a megújuló hazai védelmi ipar és a Magyar Honvédség kapcsolódni ezekhez a törekvésekhez.

\footnotetext{
4 Brussels Summit Communiqué - Issued by the Heads of State and Government participating in the meeting of the North Atlantic Council in Brussels 14 June 2021. NATO E-Library, 14. 06. 2021., 6/d bek.

5 NATO 2030 Factsheet. NATOpress, Public Diplomacy Division, 06. 2021. https://www.nato.int/nato_static_fl2014/ assets/pdf/2021/6/pdf/2106-factsheet-nato2030-en.pdf (Letöltés időpontja: 2021. 08. 04.)

6 Vivienne Machi: NATO Hopes to Launch New Defense Tech Accelerator by 2023. Defense News, 22. 06.2021. https://www.defensenews.com/global/europe/2021/06/22/nato-hopes-to-launch-new-defense-tech-acceleratorby-2023/ (Letöltés időpontja: 2021. 08. 04.)

NATO 2030 Factsheet.

8 Maija Palmer: NATO Launches $€ 1$ bn Fund to Invest in War Startups. Sifted, 22. 06. 2021. https://sifted.eu/articles/ nato-war-startups/ (Letöltés időpontja: 2021. 08. 04.)

9 Machi: i. m.
} 


\section{A NATO STRATÉGIAI ELŐRELÁTÁSÁNAK KEZDETEI: A SZÖVETSÉGES TRANSZFORMÁCIÓS PARANCSNOKSÁG LÉTREJÖTTE}

Az új évezred kezdetén az Észak-atlanti Szerződés Szervezetének a biztonsági környezete is átalakulófélben volt. A 2002 novemberében megtartott prágai csúcstalálkozó zárónyilatkozata leszögezte, hogy „,[a] Washingtoni Szerzödésben foglalt közös jövőképünkhöz híven elkötelezzük magunkat partnereinkkel a NATO átalakitása, új tagokkal való bövitése, valamint új képességek fejlesztése mellett". ${ }^{10}$ A prágai csúcs döntést hozott a Szövetség parancsnoki struktúrájának reformjáról is, amelyet a tagországok védelmi miniszterei 2003 tavaszán hagytak jóvá. ${ }^{11}$ Az újonnan létrehozott Szövetséges Transzformációs Parancsnokság (Allied Command Transformation, ACT) fö feladata az lett, hogy a NATO felkészüljön a jövőbeli kihívásokra a katonai struktúrájának és képességeinek átalakítása és folyamatos fejlesztése által, különös tekintettel a NATO-erők müveleti készenlétére, reagálóképességére és a szövetségesek közötti interoperabilitásra helyezve a hangsúlyt. ${ }^{12}$ E célok érdekében az ACT feladatai lettek: a NATO katonai alkalmazkodásának koncepcionális keretbe helyezése és megvalósítása, a képességfejlesztés, a hosszú távú stratégiai tervezés, az összhaderőnemi doktrínafejlesztés, az oktatás és a kiképzés, valamint a kapcsolattartás az akadémiai és ipari szereplőkkel is.

Ahhoz, hogy a NATO a jövő kihívásaira felkészülten tudjon működni egy dinamikusan változó biztonsági környezetben, kiemelten fontos volt az a stratégiai előrelátással (strategic foresight) foglalkozó elemzői munka, amely a távlati politikai, védelmi, gazdasági, technológiai folyamatok vizsgálata által kísérletet tett a jövőbeni biztonsági kihívások feltérképezésére. A hosszú távú trendek kutatása, elemzése és a Szövetségre gyakorolt potenciális hatásuk megértése révén a NATO képessé vált a kihívások és a kockázatok elleni hatékonyabb felkészülésre, valamint a jövőbeli lehetőségek megragadására is.

Ez a tevékenység az ACT szervezetén belül a Stratégiai Tervező és Védelempolitikai Főnökség (Strategic Plans and Policy Directorate) feladata volt, és az ACT-nek a stratégiai elörelátás területén végzett munkája hamarosan hasznosulni látszott a NATO politikai döntéshozatala és védelmi tervezési folyamata során is.

A stratégiai elörelátás területén az ACT első meghatározó eredménye az úgynevezett Jövőképek projekt (Multiple Futures Project, MFP) volt, amelynek Navigating Towards 2030 című zárójelentését 2009 áprilisában James Mattis tábornok, az ACT akkori főparancsnoka terjesztette fel a NATO stratégiai döntéshozói számára. ${ }^{13}$ A projekt célja az volt, hogy a NATO

${ }^{10}$ Prague Summit Declaration - issued by the Heads of State and Government participating in the meeting of the North Atlantic Council in Prague, Czech Republic. NATO E-Library, 21. 11. 2002., 1. bek. https://www.nato.int/ cps/en/natohq/official_texts_19552.htm? (Letöltés időpontja: 2021. 08. 29.)

${ }^{11}$ Molnár Ferenc: NATO-csúcstalálkozók Washingtontól Bukarestig. Nemzet és Biztonság, 2008. 04., 51. http:// www.nemzetesbiztonsag.hu/cikkek/molnar_ferenc-nato_csucstalalkozok_washingtontol_bukarestig.pdf(Letöltés időpontja: 2021. 08. 29.)

12 What Is Transformation? An Introduction to Allied Command Transformation. NATO Allied Command Transformation, January 2015, 3. http://www.ieee.es/Galerias/fichero/OtrasPublicaciones/Internacional/2015/ NATO_Introduction_AlliedCommand_Transformation_Jan2015.pdf (Letöltés időpontja: 2021. 08. 29.)

${ }^{13}$ A zárójelentés anyaga 21 workshop egyeztetéseinek következményeképpen állt össze, melyeken 45 szövetséges, illetve NATO-partnerország mintegy 60 intézményéböl összesen több mint 500 szakértő vett részt, képviselve az államigazgatást, a magánszektort, a civil szervezeteket és nemzetközi szervezeteket is. Multiple Future Project Navigating Towards 2030. Final Report - April 2009. NATO Allied Command Transformation, 4. https://www. act.nato.int/images/stories/events/2009/mfp/20090503_MFP_finalrep.pdf (Letöltés időpontja: 2021. 08. 05.) 
elött álló kiszámíthatatlan és meghatározhatatlan jövő ellenére módszeresen feltárja a világ változásának mozgatórugóit, és beazonosítsa azokat a trendeket, amelyek a következő 20 évben hatással lesznek a Szövetség müködésére. ${ }^{14}$

A tanulmány a változások kilenc mozgatórugóját azonosította, és ezek alapján vázolt fel négy különálló jövőképet 2030-ra vonatkozólag. Ezután felsorolta a különböző jövőképekből következő kockázatokat és fenyegetéseket, valamint megnevezett két további lehetőséget is „stratégiai meglepetésként”: a tömegpusztító fegyverek használatát, illetve egy globális szintü járványt. Végezetül a zárójelentés 33 biztonsági és 26 katonai vonatkozású következtetést tett az azonosított jövőképekhez kapcsolódóan a kockázatok és a fenyegetések vonatkozásában, valamint olyan ajánlásokat fogalmazott meg, amelyekkel a NATO-szintü stratégiai párbeszédet és az egyes nemzetek szakpolitikai megfontolásait kívánta informálni.

\section{A STRATÉGIAI ELŐRELÁTÁS HATÁSA: A HOSSZÚ TÁVÚ KATONAI KÉPESSÉGFEJLESZTÉSI PROGRAM}

A 2010-es években folytatódott a stratégiai előrelátással kapcsolatos elemzőmunka az ACT berkeiben. A 2012-es chicagói csúcstalálkozót követően a NATO Katonai Bizottsága megbízta az ACT-et, hogy készítsen egy elemzést a jövő várható biztonságpolitikai környezetéröl. ${ }^{15}$ A 2013-ban megjelent Stratégiai elörelátás elemzés (Strategic Foresight Analysis, SFA) elnevezésü jelentés ${ }^{16}$ lett az első konkrét eredménye annak a Hosszú távú katonai átalakulás (Long-Term Military Transformation, LTMT) programnak, amelynek keretében az ACT azóta is folyamatosan elemzi a jövőbeli dinamikusan változó biztonsági környezetet, az azt alakító tendenciákat, ezáltal támogatva a NATO katonai átalakulásához szükséges döntéseket és folyamatokat. ${ }^{17}$ Külön érdekessége a dolognak, hogy az ACT ez irányú képességfejlesztéseit, illetve kutatómunkáját végző főnökséget egy magyar ezredes irányította és irányítja mind a mai napig.

Az SFA mellett az LTMT-program másik fö eleme a Jövőbeli szövetséges müveletek keretei (Framework for Future Alliance Operations, FFAO) címü dokumentum, melynek első kiadása 2015-ben jelent meg, hogy a Szövetség katonai erejének átalakítására vonatkozóan képességfejlesztési ajánlásokat fogalmazzon meg 15 évre kitekintve. Összegezve, az ACT keretein belül müködő hosszú távú átalakulási folyamat két fő pillére az SFA-jelentés, amely próbál válaszokat adni a ,vajon milyen lehet a jövő?? kérdésre, valamint az FFAOdokumentum, amely a „,mit jelent mindez a haderő tekintetében? ” felvetésre fókuszál. ${ }^{18}$

14 A Multiple Futures Project - Navigating Towards 2030 zárójelentés részletes módszertana online elérhető: Annex A: The Multiple Futures Project Methodology. http://www.bits.de/NRANEU/nato-strategy/20090503_MFP_annexes. pdf (Letöltés időpontja: 2021. 08. 05.)

15 Porkoláb Imre - Szőnyegi János: NATO-megújulás vagy vissza a gyökerekhez? Honvédségi Szemle, 2013/3., 8. https:/honvedelem.hu/images/media/5f58c44b66b5b289647226.pdf (Letöltés időpontja: 2021. 08. 05.)

16 Strategic Foresight Analysis 2013 Report. NATO Headquarters Supreme Allied Commander Transformation. https://www.act.nato.int/images/stories/media/doclibrary/sfa_security_implications.pdf(Letöltés időpontja: 2021. 08. 05.)

17 Allied Command Transformation Strategic Foresight Work. NATO Headquarters Supreme Allied Commander Transformation. https:/www.act.nato.int/futures-work (Letöltés időpontja: 2021. 08. 05.)

${ }^{18}$ Framework for Future Alliance Operations 2018 Report. NATO Headquarters Supreme Allied Commander Transformation, 10. https://www.act.nato.int/images/stories/media/doclibrary/180514_ffao18.pdf (Letöltés időpontja: 2021. 08. 05.) 
Az LTMT-program szorosan kapcsolódik a NATO védelmi tervezési folyamatához (NATO Defence Planning Process) is, melynek minden lépését, de különösen az NDPP első elemét, a politikai iránymutatást (political guidance) informálják a nyilvánosan közzétett SFA- és FFAO-dokumentumok jövőorientált elemzései. ${ }^{19}$ Ezenfelül az SFA- és a FFAOdokumentumok deklarált célja az is, hogy a megállapításaikkal segítsék a tagállamok nemzeti biztonsági stratégiáit és védelmi tervezési folyamatait is.

Fontos kiemelni, hogy az ACT stratégiai előrelátás területén végzett elemzőmunkája nem egy elefántcsonttoronyban végzett elmélkedés, hanem kiterjedt és intenzív együttmúködésen és konzultáción alapuló folyamat. Már az MFP is több mint 20 alkalmas egyeztetéssorozatot tartalmazott, a későbbi dokumentumok pedig hatványozottan több katonai és civil szervezet közös szellemi termékeként nyerték el végső formájukat.

Az első, 2013-ban megjelent SFA-jelentést 2015-ben követte az első FFAO-dokumentum. 2015-ben megjelent egy köztes SFA (Interim Update) is, majd 2017-ben érkezett a menetrend szerinti újabb teljes értékü SFA-jelentés, majd 2018-ban a második FFAO-dokumentum. A soron következő SFA-anyag az ACT tervei szerint 2021 második felére várható. Az ACT stratégiai előrelátás terén végzett munkájának szemléltetéseképpen az alábbiakban röviden bemutatjuk az eddig publikált dokumentumok lényegi strukturális és tartalmi elemeit.

A 2013-as SFA szük két évtizedes periódust lefedő, 2030-ig történő kitekintést végzett, mely során épített a 2010-ben elfogadott stratégiai koncepció alapelveire és a 2009-ben lezárult MFP eredményeire is. A jelentés öt különféle területen (politika, társadalom, technológia, gazdaság és erőforrások, természeti környezet) belül azonosított összesen 15 folyamatot, melyek kapcsán 34 védelmi és biztonsági vonatkozású következtetést vont le a NATO-ra nézve. ${ }^{20}$

A 2015-ben publikált FFAO a 2013-as SFA-jelentésre közvetlenül alapozva arra tesz javaslatokat, hogy a Szövetség haderői milyen képességfejlesztéseket hajtsanak végre a 2030-ig hátralévő 15 évben. A dokumentum bevezetőjében Jean-Paul Paloméros tábornok, az ACT akkori főparancsnoka hangsúlyozta, hogy az FFAO ,olyan hosszú távú utat vázol fel, amely hasznos információkkal szolgál a stratégiai erőfeszitések számára a jövőbeli müveleti kihívások fényében". ${ }^{21}$

A 2015-ös FFAO-jelentés három részböl áll: az első fejezet röviden felidézi az SFA 2013 által részletesen elemzett jövőbeli biztonsági környezetet, majd az SFA-ban azonosított 15 globális folyamat szinergiái alapján felvázol 10 olyan kiszámíthatatlan helyzetet ${ }^{22}$ (instability situations), amelyekkel a NATO szembesülhet a 2015-2030 közötti periódusban. A jelentés függelékében bemutatják az ilyen helyzetek kontextusait, a szituációk esetleges bekövetkeztéhez hozzájáruló folyamatokat, az instabilitás okait és jellegét, valamint a 2030-as jövőképre jellemző „újdonságfaktorokat” is.

Az FFAO legfontosabb eleme az öt úgynevezett stratégiai katonai perspektíva (strategic military perspectives), amelyek az ACT főparancsnokának iránymutatásaként alapvető

19 Jordan Becker - Robert Bell: Defense planning in the fog of peace: the transatlantic currency conversion conundrum. European Security, Vol. 29, Issue 2, 20. 01. 2020., 131. https://www.tandfonline.com/doi/full/10.1080/0966283 9.2020.1716337 (Letöltés időpontja: 2021. 08. 06.)

20 Strategic Foresight Analysis 2013 Report. 43.

${ }^{21}$ Framework for Future Alliance Operations. NATO Headquarters Supreme Allied Commander Transformation, August 2015, 1. https:/www.act.nato.int/images/stories/media/doclibrary/ffao-2015.pdf(Letöltés időpontja: 2021. 08. 06.)

${ }^{22}$ Például konfliktus az euroatlanti térségben, nem állami és állami szereplők közötti konfliktus, járványok, tömegpusztító fegyverek használata. 
irányvonalakat jelölnek ki a jövőbeli katonai képességfejlesztéssel és a védelmi tervezéssel foglalkozó szakemberek számára. ${ }^{23}$

2015-ben az FFAO-jelentés debütálása mellett az LTMT-program részeként ugyanazon évben kiadtak egy időközi SFA-helyzetjelentést, amely az SFA aktualizálása volt a 2013 óta történt jelentős geopolitikai fejlemények (a Krím félsziget elfoglalása, a Kelet-Ukrajnában folytatott háború, a szíriai polgárháború elmélyülése, az Iszlám Állam előretörése, az eurózóna gazdasági gyengélkedése, az energiaárak bizonytalansága és a fokozódó klímaproblémák) kapcsán. ${ }^{24}$ A 2015-ös időközi SFA-helyzetjelentésnek három deklarált célja volt: egyrészt felülvizsgálni az SFA 2013 dokumentumban már azonosított folyamatokat, másrészt azonosítani olyan új trendeket, amelyeket a rá következő, 2017-es SFA-jelentés részleteiben elemez majd, harmadrészt pedig fenntartani az ACT stratégiai elörelátás területén végzett munkájának átláthatóságát a NATO-tagországokkal, partnerekkel, tudományos és ipari körökkel történő nyílt együttmüködés által. A 2013-as dokumentumhoz hasonlóan a 2015-ös helyzetjelentés is ugyanarra az öt fö területre fókuszált, és ezekhez füzött hozzá megállapításokat az újonnan kirajzolódó folyamatokról, viszont a tendenciákból származtatott védelmi és biztonsági jellegü következtetések tárgyalását meghagyta a 2017-es SFA-jelentés számára. ${ }^{25}$

A 2017-ben publikált SFA-jelentés struktúrájában követte az előzőekben is használt öt területi fókuszt (politika, társadalom, technológia, gazdaság és erőforrások, természeti környezet), a vizsgálódás távlatát azonban kiterjesztette 2035-ig. Az elemzőmunka az öt területen összesen 20 folyamatot azonosított, amelyekböl 59, a NATO számára védelmi és biztonsági szempontból releváns következtetést vont le. ${ }^{26}$

A 2017-es SFA fó újszerü motívuma az államokon belüli, illetve az államok közötti polarizáció fokozódása, ami a nagyhatalmak közötti versengés élesedésével egy instabilabb, érdekkonfliktusok által dominált jövőt vetít előre. A dokumentum felhívja továbbá a figyelmet a nem állami szereplők befolyásának növekedésére, valamint arra, hogy az állami és a nem állami szereplők hibrid és kibereszközökkel befolyásolják a biztonsági környezetet a konfliktusküszöb alatti szürke zónában. ${ }^{27}$ A szöveg számos helyen „különvélemény” címmel rövid ellenpontokat is tartalmaz, mivel a dokumentum készítését megelőző egyeztetési folyamatban jelentős véleménykülönbségek fordultak elö. ${ }^{28}$

${ }^{23}$ Az öt stratégiai katonai perspektíva: mủveleti tempó (operational agility); biztonsági hálózatok (security networking); megosztott reziliencia (shared resilience); stratégiai helyzettudatosság (strategic awareness); stratégiai kommunikáció (strategic communications). Uo. 15.

${ }^{24}$ Strategic Foresight Analysis 2015 Interim Update to the SFA 2013 Report. NATO Headquarters Supreme Allied Commander Transformation, 1. https://www.act.nato.int/images/stories/media/doclibrary/160121sfa.pdf(Letöltés időpontja: 2021.08. 06.)

${ }^{25}$ A dokumentumban újonnan kirajzolódó folyamatokként megnevezett trendek közül példaként említhető meg a hatalmi politika és az államok közötti fegyveres konfliktus eshetőségének visszatérése, a liberális világrend elleni kihívások erősödése, a migrációs folyamatok fokozódása, az autonóm rendszerekkel kapcsolatos technológiai fejlődés és ennek katonai vonatkozásai, illetve a jelentős természeti katasztrófák tovagyürüző hatásai.

26 Strategic Foresight Analysis 2017 Report. NATO Headquarters Supreme Allied Commander Transformation, 76-77. https://www.act.nato.int/images/stories/media/doclibrary/171004_sfa_2017_report_hr.pdf (Letöltés időpontja: 2021. 08. 06.)

27 Juhász István: Kihívások, kockázatok, fenyegetések - a katonai képességek transzformációja a jövő müveleti környezetében. Szakmai Szemle, 2021/2., 35. https://www.knbsz.gov.hu/hu/letoltes/szsz/2021_2_szam.pdf(Letöltés időpontja: 2021.08. 07.)

${ }^{28}$ E témák közé tartoznak többek között a globalizáció hatásairól, Kína felemelkedéséről, a mesterséges intelligencia hasznosításáról és a társadalmi polarizáció következményeiről szóló viták. 
A 2018-ban megjelent második FFAO-jelentés az elsőhöz hasonlóan a stratégiai előrejelzés katonai vonatkozású implikációra fókuszál, és a 2035-ös év távlati jövőképét vizsgálva fogalmaz meg javaslatokat arra vonatkozóan, hogy a NATO-erőknek a következő két évtizedben is olyan katonai képességekkel kell rendelkezniük, amelyekkel érvényesülni tudnak a jövőbeli kihívások és lehetőségek közepette. Ugyanakkor a 2015-ös FFAO-hoz képest a 2018-as változatban több jelentős különbség is megfigyelhető.

Bár a stratégiai katonai perspektívák fontossága megmaradt központi motívumként, a „,milyennek kell lenniük a haderöknek?” kérdésre viszont a 2018-as FFAO már részben eltérő, újragondolt választ adott. Az új megközelítésben a stratégiai katonai perspektívák egy átfogó központi gondolat (central idea) köré szerveződnek, amelyekröl a dokumentum így fogalmaz: „A katonai elöny megtartása és a jövőbeni müveletekben való gyözelem érdekében a NATO-eröknek folyamatosan fejlödniük, alkalmazkodniuk és újítaniuk kell, valamint hiteleseknek, hálózatositottaknak, helyzettudatosaknak, agilisaknak és ellenállóknak kell lenniük. "29 A stratégiai katonai perspektívák tehát a központi gondolatban megfogalmazott öt jellemzőt részletezik, és ennek alapján adnak támpontokat a szövetségesek transzformációs, védelmi tervezési és képességfejlesztési folyamataihoz.

Másrészt a 2018-as dokumentum kiegészült egy értekezéssel a háború Clausewitz által jellemzett állandó természetéről, ugyanakkor változó jellegéről.

A harmadik eltérés jól példázza a Szövetség biztonságikörnyezet-percepciójának romlását: míg a 2015-ös FFAO 10 kiszámíthatatlan helyzetet vázol fel, addig a 2018-as jelentés már 15 ilyen lehetséges szituációt azonosít, ráadásul rögzíti azt is, hogy ez távolról sem egy teljes körü lista.

Egy további lényegi eltérés a feltörekvő technológiák fókuszba kerülése. Ugyan már a 2015-ös FFAO-ban is szerepelt egy bekezdés azokról a feltörekvő technológiákról, amelyek a jelentés szerint a Szövetség számára lehetőségeket nyújthatnak, illetve kihívásokat jelenthetnek, ${ }^{30}$ a 2018-as FFAO jelentős változást hozott a NATO-nak a védelmi innovációhoz történő hozzáállása terén is.

Végezetül fontos kiemelni, hogy az LTMT-program stratégiai előrelátás területén végzett munkája keretében az ACT rendszeresen publikál a periodikus SFA- és FFAO-jelentéseken túl is különféle elemzéseket. Az ACT stratégiai elörelátással foglalkozó szervezeti egysége 2018-ban kezdett el regionális fókuszú anyagokat készíteni a NATO számára különleges érdeklődésre számot tartó térségek jövőbeli biztonsági környezetéről, illetve az ezekben a régiókban zajló folyamatoknak az euroatlanti térségre gyakorolt lehetséges hatásairól. Az eddig elkészült regionális fókuszú jelentések közül az első Észak-Afrikával és a Száhellel foglalkozik, míg a második Oroszországot vette szemügyre. 2021 folyamán egy-egy további jelentés várható az északi-sarkvidéki és az indiai-csendes-óceáni térségröl. Az ACT föparancsnokának utasítására a stratégiai elöre jelző részleg (Strategic Foresight Branch) 2020 óta Kína jövőjével kapcsolatos elemzőmunkát is folytat az ország felemelkedéséböl következő stratégiai következtetések levonása érdekében. Ezenfelül - gyorsan reagálva a terjedő koronavírus-járványra - az előre jelző részleg már 2020 júniusában publikált egy gondolatébresztő írást a NATO stratégiai környezetének lehetőséges változásairól a járvány alatti és az azt várhatóan követő trendek tükrében. ${ }^{31}$

\footnotetext{
${ }^{29}$ Framework for Future Alliance Operations 2018 Report, 7.

${ }^{30}$ Framework for Future Alliance Operations (2015), 41-42.

${ }^{31}$ Food for Thought (FFT) Paper: Post COVID-19 Global Security Landscape. ACT Strategic Foresight Branch, 06. 2020. https://www.act.nato.int/application/files/6716/1915/3701/20200623_fft-covid.pdf(Letöltés időpontja: 2021. 08. 07.)
} 


\section{AZ ELŐRELÁTÁS MÜVELETI HATÁSA: A NATO INNOVÁCIÓS TÖREKVÉSEI}

A stratégiai elörelátás terén végzett elemzőmunka eredményeinek elsősorban az lett az müveleti hatása, hogy központi szerepet kapott a feltörekvő és felforgató technológiák (Emerging and Disruptive Technologies, EDT) vizsgálata. Míg a 2015-ös változatban az innováció epizódszerepet kap, addig a 2018-as FFAO-jelentés már hangsúlyozza az innováció fontosságát. A központi gondolatban történő rögzítésén túl kiemeli azt is, hogy az innováció és a technológiai változások a katonai előny megőrzéséhez szükséges előnyt jelentenek, másrészt a technológiák kihasználatlansága esetén a NATO-t akár felül is múlhatják majd jövőbeli ellenfelei. ${ }^{32}$ A 2018-as FFAO-jelentés tehát komoly mérföldkő, mivel felhívja a figyelmet arra, hogy a technológiai újítások előnyös hatással lehetnek az interoperabilitásra, a müveleti hatékonyságra, a müveleti tempóra, a vezetési és irányítási rendszerekre, valamint a döntéshozatali folyamatokra is.

A technológiai trendek vizsgálata azonban nem képezi cikkünk témáját. Ehelyett elsősorban azt a kérdést szeretnénk megválaszolni, hogy a NATO-tagországok hogyan lesznek képesek újragondolni az eddigi kutatás-fejlesztési folyamataikat, valamint hogyan tudják felgyorsítani az újonnan megjelenö eszközök rendszeresítését az innováció elötérbe helyezésével.

Az innováció fogalma viszonylag új keletü eleme a NATO-csúcstalálkozók politikai nyilatkozatainak. Az innováció kifejezés nem is szerepelt például a 2010-es stratégiai koncepcióban és a 2012-es chicagói csúcstalálkozó zárónyilatkozatában sem. A 2014-es walesi csúcson elfogadott dokumentum viszont már szán egy rövid bekezdést az ,,inkluzív, fenntartható, innovativ és globálisan versenyképes védelmi ipar” fontosságának a nemzeti védelmi képességek fenntartása és fejlesztése szempontjából. ${ }^{33}$

A 2016-os varsói csúcson elfogadott zárónyilatkozat pedig már bővebben foglalkozik a kérdéssel: ebben a dokumentumban jelenik meg elsőként a Szövetség technológiai elönyének, pontosabban a technológiai előny megtartásának gondolata, valamint a feltörekvö technológiák azonosításának, katonai relevanciájuk vizsgálatának és az innovatív megoldások katonai hasznosításának motívuma is. ${ }^{34}$ A varsói csúcson elfogadott dokumentum leszögezi továbbá, hogy a NATO üdvözli azokat a védelmi célú innovációs kezdeményezéseket, amelyek az ezzel kapcsolatos szövetségen belüli együttmüködéseket támogatják és ösztönzik.

A 2018-as brüsszeli csúcstalálkozó zárónyilatkozata megerősítette a fejlődő és minden hadszíntérre hatást gyakorló képességek szerepének fontosságát. A tagállamok vezetői elkötelezettségüket fejezték ki a védelmi kiadások növelése iránt, és kiemelték a kutatás-fejlesztés, valamint az innovációs tevékenységek fontosságát a technológiai előny megőrzése érdekében. ${ }^{35}$

${ }^{32}$ Framework for Future Alliance Operations 2018 Report, 17.

33 Wales Summit Declaration - Issued by the Heads of State and Government participating in the meeting of the North Atlantic Council in Wales. NATO E-Library, 04. 09. 2014., 74. bek. https://www.nato.int/cps/en/natohq/ official_texts_112964.htm (Letöltés időpontja: 2021.08.07.)

${ }^{34}$ Warsaw Summit Declaration - Issued by the Heads of State and Government participating in the meeting of the North Atlantic Council in Warsaw 8-9 July 2016. NATO E-Library, 09. 07. 2016., 136. bek. https://www.nato. int/cps/en/natohq/official_texts_133169.htm (Letöltés időpontja: 2021. 08. 07.)

35 Brussels Summit Declaration - Issued by the Heads of State and Government participating in the meeting of the North Atlantic Council in Brussels 11-12 July 2018. NATO E-Library, 12. 07. 2018., 31. bek. https://www.nato. $\mathrm{int} / \mathrm{cps} / \mathrm{en} /$ natohq/official_texts_156624.htm (Letöltés időpontja: 2021. 08. 07.) 
Az állam- és kormányfők 2019-es londoni találkozója több szempontból is fontos változásokat hozott. Egyrészt a világür megjelent egy újabb, immáron az ötödik hadszíntérként, másrészt pedig a zárónyilatkozat szövegében a már korábban is használt technológiai elöny megőrzése célkitüzés kibővült a „,miközben megörizzük értékeinket és normáinkat” félmondattal, utalva a NATO-tagállamokban zajló etikai vonatkozású diskurzusokra a feltörekvő technológiák fejlesztése és alkalmazása kapcsán. ${ }^{36}$ Harmadrészt az állam- és kormányfők is ratifikálták a Feltörekvö és felforgató technológiák megvalósitási ütemterve (Emerging and Disruptive Technology Implementation Roadmap) elnevezésü dokumentumot, amelyet korábban, 2019 októberében a védelmi miniszterek már elfogadtak. ${ }^{37}$

A következő évben a NATO intézményrendszerén belüli változások is tükrözték, hogy a Szövetség mennyire komolyan veszi az innováció kérdéskörét. 2020-ban megalakult a NATO Innovációs Testülete (NATO Innovation Board), melynek a fent említett EDT-ütemterv megvalósításán túl feladata még az innovációhoz kapcsolódó szakpolitikák és törekvések szövetségi szintü koordinálása is. ${ }^{38}$ Létrejött továbbá egy innovációs egység (Innovation Unit) is a brüsszeli NATO-parancsnokság feltörekvő biztonsági kihívások (Emerging Security Challenges) divízióján belül, amely kifejezetten a szövetségi innovációs ökoszisztéma fejlesztésén dolgozik.

Ezt követően, 2020 júliusában Stoltenberg főtitkár felállított egy 12 fős, a magánszektorban és az egyetemi közegben müködő külsős szakértőből álló EDT Tanácsadói Csoportot (Advisory Group on Emerging and Disruptive Technologies) a NATO Innovációs Testületének támogatása érdekében. ${ }^{39}$

A Tanácsadói Csoport első éves jelentése 2021 márciusában jelent meg, amelyben öt kulcsfontosságú területen - mesterséges intelligencia és gépi tanulás; kvantumtechnológia; adatbiztonság; számítástechnikai rendszerek; biológiai és a szintetikus anyagok - jelölték ki a Szövetség közvetlen érdekeit. ${ }^{40}$ A külsős szakértők felhívják a figyelmet arra, hogy a NATO kivételes helyzetben van abban a tekintetben, hogy globálisan is motorja legyen az értékalapú technológiai innovációnak. A Tanácsadói Csoport szerint a Szövetség akkor lesz felkészült az EDT által elörevetített jövőre, amennyiben befektet az oktatásba és a tehetségfejlesztésbe, hálózati alapon müködő innovációs ökoszisztémát hoz létre NATOszerte az ipari és a tudományos világ szereplöit is bevonva, illetve átgondolja, hogy milyen szerepet vállalhat a védelmi innováció finanszírozási rendszerének kialakításában annak érdekében, hogy az agilis kis- és középvállalatok is kapcsolódhassanak a védelmi innovációs vérkeringésbe.

${ }^{36}$ London Declaration - Issued by the Heads of State and Government participating in the meeting of the North Atlantic Council in London 3-4 December 2019. NATO E-Library, 04. 12. 2019., 6. bek. https://www.nato.int/ cps/en/natohq/official_texts_171584.htm (Letöltés időpontja: 2021. 08. 07.)

${ }^{37}$ Emerging and disruptive technologies. NATO E-Library, 18. 06. 2021. https://www.nato.int/cps/en/natohq/ topics_184303.htm (Letöltés időpontja: 2021. 08. 07.)

${ }^{38}$ Simona R. Soare: Innovation as Adaptation: NATO and Emerging Technologies. German Marshall Fund of the United States, 11. 06. 2021. https://www.gmfus.org/news/innovation-adaptation-nato-and-emerging-technologies (Letöltés időpontja: 2021. 08. 07.)

${ }^{39}$ Uo.

${ }^{40}$ NATO Advisory Group on Emerging and Disruptive Technologies - Annual Report 2020. 09. 03. 2021., 9. https:// www.nato.int/nato_static_fl2014/assets/pdf/2021/3/pdf/210303-EDT-adv-grp-annual-report-2020.pdf (Letöltés időpontja: 2021. 08. 08.) 
A NATO-fötitkár által kinevezett Reflexiós Csoport (Reflection Group) 2020. november végén, több hónapos intenzív egyeztetés után közreadott jelentése ${ }^{41}$ is külön fejezetet szentelt az innováció és az EDT témakörének. A Reflexiós Csoportot a londoni találkozón megfogalmazódott önvizsgálati igény nyomán jelölte ki a fötitkár 2020 márciusában azzal a céllal, hogy egy külső nézőponttal támogassa a Szövetség jövőállóságát célzó, NATO 2030 néven futó közös gondolkodási folyamatot.

A Reflexiós Csoport jelentése szerint bár az innováció és a képességfejlesztés elsősorban nemzeti szinten történik, a NATO kulcsfontosságú koordináló intézmény szerepét töltheti be, és ennek megfelelően kellene szolgálnia a szövetségesek közötti információmegosztást és együttmüködést - erre alkalmas más transzatlanti léptékü koordinációs eszköz híján. ${ }^{42}$ A javaslatok között megtalálható továbbá egy NATO-szintủ védelmi innovációt támogató szervezet létrehozása az amerikai Fejlett Védelmi Kutatási Projektek Ügynöksége (DARPA ${ }^{43}$ ) vagy az Európai Védelmi Alap $\left(\mathrm{EDF}^{44}\right)$ mintájára. Szorosan ehhez kapcsolódóan a jelentés egy másik fejezete tartalmaz egy javaslatot egy szövetségi kockázatitöke-alap létrehozására is, amely tagállami befektetéseket követően újszerü finanszírozási módszerként nyithatna utat az innovatív startup világhoz. ${ }^{45}$

A NATO innovációs törekvései terén a következő mérföldkőre 2021 februárjában került sor, amikor a NATO védelmi miniszterei elfogadták a Koherens végrehajtási stratégia a feltörekvö és felforgató technológiákról (Coherent Implementation Strategy on Emerging and Disruptive Technologies) címü dokumentumot, amely irányt mutat a Szövetségnek a feltörekvő és felforgató technológiák átvételére vonatkozóan, valamint javaslatokat fogalmaz meg az azokhoz való alkalmazkodás terén. A dokumentum két fó fókusza egyrészt a kettős felhasználású technológiák fejlesztésének előmozdítása, másrészt a NATO transzatlanti fórumként való müködése a fenyegetések elleni védelmet segítő jó gyakorlatok megosztása révén.

A Koherens Végrehajtási Stratégiában megjelölt hét technológiai prioritás ${ }^{46}$ mindegyikéröl különálló stratégiai dokumentum készül, amely közül az első, a NATO mesterségesintelligencia-stratégiája várhatóan még 2021 harmadik negyedévében megjelenik. ${ }^{47}$

Végül, ahogyan azt a bevezetőben is kifejtettük, a legfrissebb és akár hosszú távon is legkiemelkedőbbnek számító gyakorlati fejlemények a 2021. júniusi brüsszeli csúcstalálkozóhoz köthetők, ahol a védelmi innováció terén két új intézmény létrehozásáról is határoztak. Az egyik az Észak-atlanti Védelmi Innovációs Akcelerátor (Defence Innovation Accelerator for the North Atlantic), a másik pedig a NATO Innovációs Alap (NATO Innovation Fund).

A NATO reményei szerint ezek a szervezetek hivatottak arra, hogy erősítsék a tagállamok ipari bázisai közötti együttmüködést, áthidalják az innovációs hiányosságokat és támogassák a fö célkitűzést: nevezetesen, hogy a Szövetség gyorsabban tudjon alkalmazkodni, illetve

${ }^{41}$ NATO 2030: United for a New Era. Analysis and Recommendations of the Reflection Group Appointed by the NATO Secretary General. 25. 11.2020. https://www.nato.int/nato_static_fl2014/assets/pdf/2020/12/pdf/201201Reflection-Group-Final-Report-Uni.pdf (Letöltés időpontja: 2021. 08. 08.)

42 Uo. 13.

43 Defense Advanced Research Projects Agency.

44 European Defence Fund.

45 NATO 2030: United for a New Era. 63.

${ }^{46}$ Mesterséges intelligencia; adattudomány és számítástechnika; autonóm rendszerek; kvantumtechnológia; biotechnológia és az embert fejlesztő technológiák; hiperszonikus technológiák; ürtechnológia.

47 Vivienne Machi: Artificial intelligence leads NATO's new strategy for emerging and disruptive tech. C4ISRNet, 15. 03. 2021. https://www.c4isrnet.com/artificial-intelligence/2021/03/14/artificial-intelligence-leads-natos-newstrategy-for-emerging-and-disruptive-tech/ (Letöltés időpontja: 2021. 08. 08.) 
képes legyen a technológia felgyorsult fejlődési és megjelenési tempójának megfelelő ütemben rendszeresíteni új technológiákat. ${ }^{48}$

Összességében megállapítható, hogy a NATO védelmi innovációs törekvései rendkívüli mértékben felgyorsultak az elmúlt néhány évben, így a magyar haderő szempontjából a közeljövő fö kérdése az lesz, hogyan tudjuk a hazai védelmi ipari szempontokat képviselni, hogyan tudunk aktív szerepvállalást biztosítani és befolyást gyakorolni a NATO innovációs szervezeteivel az együttmúködés során, illetve hogyan kívánjuk támogatni a részvételt a NATO Innovációs Alapban.

\section{A VÉDELMI INNOVÁCIÓ MAGYAR VONATKOZÁSAI}

Orbán Viktor, Magyarország miniszterelnöke a Bledben 2020. augusztus 30-án tartott stratégiai fórumon ${ }^{49}$ hangsúlyozta, hogy a közép-európai régió egyik stratégiai előnye a védelmi iparhoz kapcsolódó kutatás-fejlesztési kapacitások kihasználása lehet. Ennek a víziónak a tükrében érthető, hogy a haditechnológia csupán egy eszköz, és valójában a stratégiai előnyt egy a nemzetközi rendszerhez kapcsolódó nemzeti védelmi innovációs rendszer megteremtése jelenti, amelynek elemei az oktatást is magában foglaló védelmi innovációs ökoszisztéma, egy hosszú távú kutatás-fejlesztési elképzelés, valamint az ezekre épülő védelmi ipari cégek, amelyek támogatni tudják a kettős felhasználású technológiák fejlesztését.

A hazai biztonságpolitikai szakértők - a NATO szakértőihez hasonlóan - szintén felhívják a figyelmet a kiszámíthatatlanságra, amit az is bizonyít, hogy a nemzeti biztonsági stratégiánk az új kihívások tekintetében hangsúlyozza a technológiai forradalom társadalomformáló hatásait is ${ }^{50} \mathrm{~A}$ stratégia kitér a hazai védelmi ipar, azon belül is a kutatás-fejlesztés és az innováció támogatására, azt nemzetbiztonsági érdekként azonosítja, mivel ezek által csökkenthető az importfüggőség, növelhető az ellátásbiztonság és a védelmi eszközök hazai gyártmányokkal korszerüsíthetők.

A stratégia szerint a forradalmi technológiák fejlesztése stratégiai fontosságú kérdés. Hazánk biztonsága megkívánja, hogy a kulcsfontosságú területeken - mint például a kibervédelem, a mesterséges intelligencia, az autonóm rendszerek, a biotechnológia - kiemelt figyelmet fordítsunk a kutatás-fejlesztésre és annak védelmi összetevőjére.

Mindez nem véletlen, hiszen a hazai védelmi ipari környezet lehetőségeket rejt magában. Az újonnan megjelenő nemzetközi védelmi ipari nagyvállalatok megjelenésével a hazai védelmi ipari piacon egyre több nagyvállalkozás (úgynevezett integrátor) kialakítására is lehetőség kínálkozik, amelyek képesek támogatni a hazai kutatás-fejlesztési bázist, mindez pedig elvezethet odáig, hogy megteremtjük a feltételeket a nemzetközi innovációs projektekbe történő bekapcsolódáshoz.

A Magyar Honvédség tekintetében cél a katonai elöny fejlesztése és fenntartása azáltal, hogy szervezetet adaptívvá alakítjuk, vagyis képessé kell tenni a haderőt a rendkívül gyorsan változó biztonsági környezet kezelésére, az új technológiák szinte azonnali rendszeresítésére, valamint az alkalmazási készenlét elérésére.

\footnotetext{
${ }^{48}$ NATO 2030 Factsheet.

49 Viktor Orbán at the Bled Strategic Forum. Miniszterelnöki Kormányiroda, 31. 08. 2020. https://www.miniszterelnok. hu/viktor-orban-at-the-bled-strategic-forum/ (Letöltés időpontja: 2021. 08. 08.)

50 1163/2020. (IV. 21.) Korm. határozat Magyarország Nemzeti Biztonsági Stratégiájáról. Magyar Közlöny, 2020/81., 2101. https://magyarkozlony.hu/hivatalos-lapok/2NGUpJ514oAaRpmHiGFq5e98d4798d150/dokumentumok/6c 9e9f4be48fd1bc620655a7f249f81681f8ba67/letoltes (Letöltés időpontja: 2021. 08. 30.)
} 
A Magyar Honvédség modernizációjára elengedhetetlenül szükség van, a védelmi képességek átalakítását a meghirdetett Honvédelmi és Haderőfejlesztési Program keretében hajtja végre. ${ }^{51}$ A program célja a katonai előny elérése és megőrzése, de ennek érdekében nemcsak új eszközök beszerzésére van szükség, hanem arra is, hogy a haderőt tanuló szervezetté átalakítsuk át.

A modernizáció egyértelmüen látható. A 2019-ben megrendezett budaörsi haditechnikai bemutatón már láthattuk az Airbus H145 típusú helikopterek ${ }^{52}$ első példányait. Bemutatták a Leopárd 2A4 harckocsikat is, amelyeket azóta már rendszeresítettek is, az A7+ változat pedig a 2023-as rendszeresítésével újabb generációs ugrást tesz lehetővé a Magyar Honvédség számára. A gyalogsági harcjármüvek tekintetében szintén arról született döntés, hogy a Magyar Honvédség a legmodernebb típust szerzi be. Palkovics László innovációs és technológiai miniszter és Maróth Gáspár védelmi fejlesztésekért felelős kormánybiztos közös közleményükben hangsúlyozták, hogy Magyarország a NATO-nak tett vállalásai részeként helyreállítja szárazföldi haderejének nehézfegyverzetét. „A harckocsikat és a tüzérséget követően rövidesen a képességcsomag gerincét alkotó gyalogsági harcjármüvekre kerül sor" "53 - fogalmaztak, hozzátéve: kategóriájában a legkorszerübb típusként a Lynx páncélozott gyalogsági harcjármü bizonyult alkalmasnak arra, hogy az elkövetkező évtizedekben ezt a központi szerepet betöltse az MH eszközparkjában.

A modernizáció fontosságáról beszélt Maróth Gáspár, amikor felhívta a figyelmet arra, hogy „Magyarország 2014 óta rendelkezik saját védelmi ipari stratégiával, jelenleg ennek az aktualizálása zajlik”. Maróth arról is beszélt, hogy 2021-ben „, a kutatás-fejlesztési projektek és gyártelepitések beinditása viszi a prioritást, elsö lépésként ezek összehangolása végett létrehozzuk a Védelemipari Kutatóintézetet, ahova koncentráljuk a hazai és külföldi erőforrásainkat a programok beindításához,. ${ }^{54}$

Az új eszközök beszerzésével tehát a Magyar Honvédség egy új korszakba lépett. A Honvédelmi és Haderőfejlesztési Program megvalósítása azonban jócskán túlmutat a modernizáción. Az újonnan beszerzésre tervezett eszközök rendszeresítése magával hozza az egész oktatási, képzési és felkészítési spektrum átalakítását. Ezek szinte kivétel nélkül innovációs feladatok. A szövetségi rendszerek kereteit tehát felhasználhatjuk együttes képességfejlesztésekre, de ki kell tágítani ezeket az együttmüködéseket a szoros értelemben vett haderöfejlesztésen túl az innovációs együttmüködések irányába.

Nem elég azonban itt megállni, hiszen manapság sok katonai újítás a civil szektorból származik. Egy innovációs rendszer hiányában a fegyveres erők sajnos csak akkor figyelnek fel ezekre az újításokra, amikor azok megjelennek a kereskedelmi célú drónokban, az

51 A magyar kormány a hidegháború vége óta a legjelentősebb fejlesztési programot indította be, amely érinti a Magyar Honvédség minden szegmensét, sőt kiterjed a védelmi iparra is. Az MH modernizálása nagy volumenű beszerzési tervet is magában foglal a védelmi ipar újjáélesztése érdekében, amelyet tudástranszfer, technológiai korszerüsítés és a védelmi ipar kapacitásainak létrehozása útján hajtanak végre.

${ }^{52} \mathrm{H} 145 \mathrm{M}$ - The battlefield support helicopter. Airbus. https://www.airbus.com/helicopters/military-helicopters/ light/h145m.html (Letöltés időpontja: 2021. 08. 08.)

53 Stephen Kuper: Rheinmetall secures launch customer for KF-41 Lynx IFV. Defence Connect, 19. 08. 2020. https:// www.defenceconnect.com.au/land-amphibious/6668-rheinmetall-secures-launch-customer-for-kf-41-lynx-ifv (Letöltés időpontja: 2021. 08. 30.)

${ }^{54}$ Huszák Dániel: 2021-ben is dübörög a magyar hadiipar fejlesztése-Megtudtuk, mit tervez a kormány. Portfolio, 2021. 02. 10. https://www.portfolio.hu/global/20210210/2021-ben-is-duborog-a-magyar-hadiipar-fejlesztesemegtudtuk-mit-tervez-a-kormany-465188; Ösztől épül a kaposvári fegyvergyár. Mandiner, 2021. 04. 15. https:// mandiner.hu/cikk/20210415_osztol_epul_a_kaposvari_fegyvergyar (Letöltések időpontja: 2021. 08. 08.) 
információs hálózatok ellen indított kibertámadások során, a mesterséges intelligenciával támogatott autonóm rendszerekben, vagy esetleg a biotechnológia és a neurobiológia által előállított újdonságokban.

A Magyar Honvédség sem tudja önállóan végrehajtani a kutatás-fejlesztési feladatokat, ezért részt kell vennie olyan interfészelemek kiépítésében, amelyek segítenek csatlakozni a már meglévő civil innovációs ökoszisztémához. Ennek első lépése volt a 2018-ban létrehozott MH Modernizációs Intézet, amelynek feladata a már meglévő kutatás-fejlesztési folyamatok újragondolása és egy új védelmi innovációs rendszer alapjainak lerakása. A 2020-ban létrejött MH Transzformációs Parancsnokság pedig azt a feladatot vállalta fel, hogy tanuló szervezetté alakítsa át a Magyar Honvédséget.

Ezen túlmenően azonban szükség volt egy olyan interfészszervezetre is, amely a civil innovációs kezdeményezéseket karolja fel és köti össze a védelmi fejlesztésekkel. Erre a felismerésre jutottak a védelmi ipari stratégia készítői is, valamint az Innovációs és Technológiai Minisztérium, melynek vezetője 2021-ben bejelentette a Védelmi Innovációs Kutatóintézet létrehozását és a finanszírozásra egy védelmi ipari kockázatitőke-alap létesítését. ${ }^{55}$

A hazai startup ökoszisztéma mindehhez olyan tehetségbázist nyújthat, amelyet ki kell használni a védelmi problémák megoldása érdekében. A NATO által kiemelt fókuszterületekhez kapcsolódóan hazánkban is különösen érdekesek lehetnek az automatizált terepjárók, a hidrogén üzemanyagcellákra épülő hibrid energiaforrások által támogatott energiarendszerek, a mesterséges intelligencián alapuló dinamikus útvonaltervezés, a kvantumkriptográfiai algoritmusok, a mesterséges valóság/virtuális valóság alapú szimulációs rendszerek, valamint a vezető nélküli rendszereken alapuló repüléstechnikai képességek fejlesztése.

\section{KÖVETKEZTETÉSEK}

Összességében azt kell felismernünk, hogy egy jól működö, a NATO-törekvésekkel összhangban lévő kutatás-fejlesztési és innovációs $(\mathrm{KF}+\mathrm{I})$ rendszer hazánk biztonságának egyik elengedhetetlen záloga. A védelmi innováció valójában az a képesség, amely segít a leghatékonyabb technológia és harcászati módszerek lehető leggyorsabb és legköltséghatékonyabb eljuttatásában a végfelhasználóhoz, vagyis a harcoló katonákhoz. ${ }^{56}$

A védelmi innováció tehát nemcsak technológiai fejlesztésekről szól, hanem szemléletváltást is feltételez, ennek eredményeként hatással van a hadviselési elvekre, a gondolkodásmódra, ezáltal megváltoztatja a haderő szervezeti kultúráját, növelve annak hadrafoghatóságát, biztosítva az interoperabilitást, illetve fenntartva a versenyképességet.

A NATO által felkínált helyzet óriási lehetőséget rejt magában, ugyanakkor feladatokat is ró a hazai képességfejlesztéssel foglalkozó szakemberekre, akiknek a magyar érdekeket szem elött tartva kell az alábbi problémákra választ adni:

1. A növekvő költségvetés során tervezett beszerzések mellett a hagyományos kutatásfejlesztési kezdeményezéseken túl innovációs programokat is be kell terveznünk a költségvetésbe.

2. Szükség van arra, hogy folyamatosan nyomon kövessük az innovációs ökoszisztémában zajló fejlesztéseket, valamint képessé kell válnunk arra, hogy értékalapú partnerségre

\footnotetext{
55 Palkovics László: Védelmi ipari stratégia készül. Magyar Nemzet, 2021. 01. 21. https://magyarnemzet.hu/gazdasag/ palkovics-laszlo-vedelmi-ipari-strategia-keszul-9257876/ (Letöltés időpontja: 2021. 08. 08.)

${ }^{56}$ Porkoláb Imre: Védelmi Innováció és katonai képességfejlesztés. In: Mernyei Ákos - Orbán Balázs (szerk.): Magyarország 2020: 50 tanulmány az elmúlt 10 évből. MCC Press Kft., 2021.
} 
lépjünk azokkal a civil szervezetekkel, amelyek megoldásokat adhatnak a védelmi jellegü problémákra.

3. A NATO-tagállamok között kölcsönös érdek az innovációs tapasztalatok megosztása, ezért aktívan, sőt proaktívan hozzá kell járulnunk a KF+I terén szerzett tapasztalataink megosztásához a Szövetség keretein belül a DIANA-ban történő részvételünkkel és a Védelmi Innovációs Alap támogatásával.

4. Nem szabad arról sem megfeledkeznünk, hogy a technológiai fejlesztések egyik legfontosabb összetevője a humándimenzió, hiszen az emberi adaptációs képességnek, a döntéshozatalnak és a szervezeti tanulási folyamatoknak lépést kell tartaniuk a technológiai fejlesztésekkel. Éppen ezért kiemelt figyelmet kell fordítani az emberi kognitív dimenzióhoz kapcsolódó kutatás-fejlesztéssel foglalkozó intézmények és kutatóintézetek támogatására.

Egy innovációfókuszú védelmi képességfejlesztési stratégia segítséget nyújt abban, hogy a technológiára csupán eszközként tekintsünk. A jövő konfliktusaiban a siker kivívásához a biztos alapokon álló védelmi ipar jó alapot szolgáltathat, de a tartós versenyképesség megszerzése és fenntartása érdekében arra van szükség, hogy a rendelkezésre álló technológiai eszközöket újszerü módon használjuk. Mindez a tradicionális technológiai fejlesztéseken (modernizáción) túl megköveteli a haderő szemléletmódjának és szervezeti kultúrájának az átalakítását, illetve komoly hangsúlyt helyez a honvédek adaptív készségeinek és tanulási képességének fejlesztésére - vagyis az innovációra.

\section{FELHASZNÁLT IRODALOM}

1163/2020. (IV. 21.) Korm. határozat Magyarország Nemzeti Biztonsági Stratégiájáról. Magyar Közlöny, 2020/81., 2101-2119. https://magyarkozlony.hu/hivatalos-lapok/2NGUpJ514oAaRpmHiGFq5e98 d4798d150/dokumentumok/6c9e9f4be48fd1bc620655a7f249f81681f8ba67/letoltes

Allied Command Transformation Strategic Foresight Work. NATO Headquarters Supreme Allied Commander Transformation. https://www.act.nato.int/futures-work

Annex A: The Multiple Futures Project Methodology. http:/www.bits.de/NRANEU/nato-strategy /20090503_MFP_annexes.pdf

Becker, Jordan - Bell, Robert: Defense planning in the fog of peace: the transatlantic currency conversion conundrum. European Security, Vol. 29, Issue 2, 20. 01. 2020., 124-148. https://www.tandfonline. com/doi/full/10.1080/09662839.2020.1716337; DOI: 10.1080/09662839.2020.1716337

Brussels Summit Communiqué - Issued by the Heads of State and Government participating in the meeting of the North Atlantic Council in Brussels 14 June 2021. NATO E-Library, 14. 06. 2021., 37. bek. https://www.nato.int/cps/en/natohq/news_185000.htm?selectedLocale=en

Brussels Summit Declaration - Issued by the Heads of State and Government participating in the meeting of the North Atlantic Council in Brussels 11-12 July 2018. NATO E-Library, 12. 07. 2018. https:// www.nato.int/cps/en/natohq/official_texts_156624.htm

Emerging and disruptive technologies. NATO E-Library, 18. 06. 2021. https://www.nato.int/cps/en/ natohq/topics_184303.htm

Food for Thought (FFT) Paper: Post COVID-19 Global Security Landscape. ACT Strategic Foresight Branch, 06. 2020. https://www.act.nato.int/application/files/6716/1915/3701/20200623_fft-covid.pdf

Framework for Future Alliance Operations 2018 Report. NATO Headquarters Supreme Allied Commander Transformation, 10. https://www.act.nato.int/images/stories/media/doclibrary/180514 ffaol8.pdf 
Framework for Future Alliance Operations. NATO Headquarters Supreme Allied Commander Transformation, August 2015. https:/www.act.nato.int/images/stories/media/doclibrary/ffao-2015.pdf

H145M - The battlefield support helicopter. Airbus. https:/www.airbus.com/helicopters/militaryhelicopters/light/h145m.html

Huszák Dániel: 2021-ben is dübörög a magyar hadiipar fejlesztése-Megtudtuk, mit tervez a kormány. Portfolio, 2021. 02. 10. https://www.portfolio.hu/global/20210210/2021-ben-is-duborog-a-magyarhadiipar-fejlesztese-megtudtuk-mit-tervez-a-kormany-465188

Juhász István: Kihívások, kockázatok, fenyegetések - a katonai képességek transzformációja a jövö müveleti környezetében. Szakmai Szemle, 2021/2., 23-45. https://www.knbsz.gov.hu/hu/letoltes/ szsz/2021_2_szam.pdf

Stephen Kuper: Rheinmetall secures launch customer for KF-41 Lynx IFV. Defence Connect, 19. 08. 2020. https://www.defenceconnect.com.au/land-amphibious/6668-rheinmetall-secures-launchcustomer-for-kf-41-lynx-ifv

London Declaration - Issued by the Heads of State and Government participating in the meeting of the North Atlantic Council in London 3-4 December 2019. NATO E-Library, 04. 12. 2019. https:// www.nato.int/cps/en/natohq/official_texts_171584.htm

Machi, Vivienne: Artificial intelligence leads NATO's new strategy for emerging and disruptive tech. C4ISRNet, 15. 03. 2021. https:/www.c4isrnet.com/artificial-intelligence/2021/03/14/artificialintelligence-leads-natos-new-strategy-for-emerging-and-disruptive-tech/

Machi, Vivienne: NATO Hopes to Launch New Defense Tech Accelerator by 2023. Defense News, 22. 06. 2021. https://www.defensenews.com/global/europe/2021/06/22/nato-hopes-to-launch-new-defensetech-accelerator-by-2023/

Molnár Ferenc: NATO-csúcstalálkozók Washingtontól Bukarestig. Nemzet és Biztonság, 2008. 04., 48-57. http://www.nemzetesbiztonsag.hu/cikkek/molnar_ferenc-nato_csucstalalkozok_washingtontol_ bukarestig.pdf

Multiple Future Project - Navigating Towards 2030. Final Report - April 2009. NATO Allied Command Transformation. https://www.act.nato.int/images/stories/events/2009/mfp/20090503_ MFP_finalrep.pdf

NATO 2030 Factsheet. NATOpress, Public Diplomacy Division, 06. 2021. https:/www.nato.int/ nato_static_fl2014/assets/pdf/2021/6/pdf/2106-factsheet-nato2030-en.pdf

NATO 2030: United for a New Era. Analysis and Recommendations of the Reflection Group Appointed by the NATO Secretary General. 25. 11. 2020. https:/www.nato.int/nato_static_fl2014/assets/ pdf/2020/12/pdf/201201-Reflection-Group-Final-Report-Uni.pdf

NATO Advisory Group on Emerging and Disruptive Technologies - Annual Report 2020. 09. 03. 2021. https://www.nato.int/nato_static_fl2014/assets/pdf/2021/3/pdf/210303-EDT-adv-grp-annualreport-2020.pdf

Ősztől épül a kaposvári fegyvergyár. Mandiner, 2021. 04. 15. https://mandiner.hu/cikk/20210415 osztol_epul_a_kaposvari_fegyvergyar

Palkovics László: Védelmi ipari stratégia készül. Magyar Nemzet, 2021. 01. 21. https://magyarnemzet. hu/gazdasag/palkovics-laszlo-vedelmi-ipari-strategia-keszul-9257876

Palmer, Maija: NATO Launches $€ 1$ bn Fund to Invest in War Startups. Sifted, 22. 06. 2021. https://sifted. eu/articles/nato-war-startups/

Porkoláb Imre: Védelmi Innováció és katonai képességfejlesztés. In: Mernyei Ákos - Orbán Balázs (szerk.): Magyarország 2020: 50 tanulmány az elmúlt 10 évből. MCC Press Kft., 2021.

Porkoláb Imre - Szőnyegi János: NATO-megújulás vagy vissza a gyökerekhez? Honvédségi Szemle, 2013/3., 7-9. https://honvedelem.hu/images/media/5f58c44b66b5b289647226.pdf 
Prague Summit Declaration - issued by the Heads of State and Government participating in the meeting of the North Atlantic Council in Prague, Czech Republic. NATO E-Library, 21. 11. 2002., 1. bek. https://www.nato.int/cps/en/natohq/official_texts_19552.htm?

Soare, Simona R.: Innovation as Adaptation: NATO and Emerging Technologies. German Marshall Fund of the United States, 11. 06. 2021. https://www.gmfus.org/news/innovation-adaptation-natoand-emerging-technologies

Strategic Foresight Analysis 2013 Report. NATO Headquarters Supreme Allied Commander Transformation. https://www.act.nato.int/images/stories/media/doclibrary/sfa_security_implications.pdf

Strategic Foresight Analysis 2015 Interim Update to the SFA 2013 Report. NATO Headquarters Supreme Allied Commander Transformation. https://www.act.nato.int/images/stories/media/ doclibrary/160121sfa.pdf

Strategic Foresight Analysis 2017 Report. NATO Headquarters Supreme Allied Commander Transformation. https://www.act.nato.int/images/stories/media/doclibrary/171004_sfa_2017_ report_hr.pdf

Viktor Orbán at the Bled Strategic Forum. Miniszterelnöki Kormányiroda, 31. 08. 2020. https://www. miniszterelnok.hu/viktor-orban-at-the-bled-strategic-forum/

Wales Summit Declaration - Issued by the Heads of State and Government participating in the meeting of the North Atlantic Council in Wales. NATO E-Library, 04. 09. 2014. https://www.nato.int/cps/ en/natohq/official_texts_112964.htm

Warsaw Summit Declaration - Issued by the Heads of State and Government participating in the meeting of the North Atlantic Council in Warsaw 8-9 July 2016. NATO E-Library, 09. 07. 2016. https:// www.nato.int/cps/en/natohq/official_texts_133169.htm

What Is Transformation? An Introduction to Allied Command Transformation. NATO Allied Command Transformation, January 2015. http://www.ieee.es/Galerias/fichero/OtrasPublicaciones/Internacional /2015/NATO_Introduction_AlliedCommand_Transformation_Jan2015.pdf 